\title{
Eradication of invasive Carpobrotus sp.: effects on soil and vegetation
}

Julie Chenot ${ }^{1}$, Laurence Affre ${ }^{1}$, Raphael Gros ${ }^{1}$, Laura Dubois ${ }^{1}$, Sarah Malecki ${ }^{1}$, Aurélie Passetti $^{1}$, Annie Aboucaya ${ }^{2}$, Elise Buisson ${ }^{1 *}$

1. Université d'Avignon et des Pays de Vaucluse, Aix Marseille Université, CNRS, IRD, IMBE; Institut Méditerranéen de Biodiversité et d'Ecologie, IUT d'Avignon, AGROPARC BP 61207, 84911 Avignon cedex 9, France.

chenot.julie@gmail.com, laurence.affre@imbe.fr, duboislaura@laposte.net, $\quad$ sarahmalecki@hotmail.fr, elise.buisson@univ-avignon.fr

2. Parc national de Port-Cros; Allée du Castel Ste-Claire, BP 70220, 83406 Hyères cedex, France. annie.aboucaya@portcros-parcnational.fr

* Corresponding author: Elise Buisson, elise.buisson@univ-avignon.fr, Phone: +33 4908438 58, Fax: +33490843807

Running title: Carpobrotus eradication effect on soil and vegetation

\section{Author contributions}

LA, RG, AP, AA, EB targeted the research question; LA, RG, EB designed the study; JC, LA, LA, SM, EB carried out field work and preliminary data analysis; JC, LA, RG, AA, EB contributed to writing and revising the manuscript.

Key words: Bagaud Island; biological invasion; Carpobrotus affine acinaciformis;

Carpobrotus edulis; invasive species control; pest management; small Mediterranean island; strict nature reserve 


\section{Abstract}

Invasive species management (eradication or control) can be used to promote native plant restoration. The objective of this study is to evaluate different treatments to guide the selection of future modalities for the eradication (i.e. elimination of all individuals in a population) of Carpobrotus sp. from a strict nature reserve. Two removal methods were tested: (1) living Carpobrotus removal; (2) living Carpobrotus and litter removal. To assess the effectiveness of each treatment, we studied the recolonization of native vegetation, the recolonization of Carpobrotus and soil erosion and compared these metrics to those taken in native vegetation and in patches of intact Carpobrotus. We also tested the capacity of a $50 \mathrm{~cm}$-wide Carpobrotus strip to retain soil. The removal of Carpobrotus together with its litter led to high rates of soil erosion. The Carpobrotus strips were found to retain the soil rather well. Removing live Carpobrotus while leaving its litter in place reduced soil erosion and led to higher native plant species recolonization. The composition of the vegetation 10 months after applying the treatments was biased in favor of native pioneer species. These are typically the first species to establish (Aetheoriza bulbosa and Arisarum vulgare resprouted, Frankenia hirsuta and Lotus cytisoides germinated, and Sonchus sp. benefited from long-distance dispersal). Few weedy species were recorded (e.g. Sonchus asper asper). Whatever the treatment, the risk of reinvasion from the seed bank or from resprouting stems is non-negligible, so long-term monitoring is vital to the ultimate success of the eradication program.

\section{Implication for practice}

- The removal of Carpobrotus alone, leaving its litter on site, increases the risks of Carpobrotus germination from the seed bank, and thus induces higher post-removal follow-up costs

- The removal of Carpobrotus and its litter leads to massive soil erosion, and thus requires finding mitigation solutions (e.g. geotextile on steeper slopes)

- Leaving a 50-cm strip of Carpobrotus downhill from where Carpobrotus and its litter is removed serves to significantly reduce the amount of soil exported from that area, but requires management while in place (cutting flowers, trimming)

- Whatever the treatment, long-term removal of germination and resprout, along with adequate funding, are vital to the ultimate success of the eradication program

\section{Introduction}

Biological invasions are one of the main threats to native biodiversity (Richardson et al. 2000; Milbau \& Stout 2008). Human activities, including national and international commercial exchanges, are responsible for increased species introductions and invasions (Vitousek et al. 1996; McKinney \& Lockwood 1999; Mack et al. 2000; Mooney \& Cleland 2001; Vilà et al. 2011; van Kleunen et al. 2015). Invasive species lead to drastic changes in native ecosystem composition and functioning (D'Antonio \& Haubensak 1998), and to native species regression or local extinction (Vitousek et al. 1996; Mack et al. 2000; Vilà et al. 2011). Moreover, they have important impacts on agriculture, fisheries, public health, and recreation, and consequently lead to costly actions of local ecological remediation (Born et al. 2005; Chenot et al. 2014).

Island ecosystems are particularly vulnerable to biological invasions (Sax et al. 2002; Sax \& Gaines 2008) because of their geographical isolation, ecological characteristics, low species richness, and disharmonic and simple food webs with high rates of endemism (Nunn 1994; Cronk 1997; Denslow 2001; Drake et al. 2002; Whittaker \& Fernandez-Palacios 2007). Invasive species introduction has led to many deleterious ecological impacts on native ecosystems that are disproportionate when compared to the analogous effects in continental areas (Courchamp et al. 2003; Trevino et al. 2007; Berglund et al. 2009; Simberloff et al. 2013). 
Because of this, island ecosystems are frequently marked by local extinctions of native species (Ricketts et al. 2005).

Invasive species eradication via the complete elimination of all individuals in a population (Simberloff et al. 2013) can be an effective tool for the management and restoration of island native plant communities. Some examples of successful eradication operations can be found in the literature (Loope et al. 2006); particularly where island environments are concerned (Mack et al. 2000; Cacho et al. 2006; Mack \& Lonsdale 2011). Such environments present the advantage to be isolated by water and thus to have limited risks of reinvasion (Saunders \& Denny 2005). The eradication of invasive species can have beneficial environmental results, from the recovery of native plant species communities (Andreu et al. 2010) to the restoration of soil properties (Vilà et al. 2006; Marchante et al. 2008; Santoro et al. 2011) and the restoration of ecological processes at the ecosystem level (Gratton \& Denno 2006; Marchante et al. 2008). However, undesirable ecological effects can occur (e.g. drastic increased in height and coverage of another non-native plant species, diet change of phytophagous species towards native species, etc.; Courchamp et al. 2011) and must be foreseen through thorough knowledge on the species (Zavaleta et al. 2001).

The Carpobrotus species found in this study are Carpobrotus edulis and Carpobrotus affine acinaciformis (Aizoaceae). Originating from South Africa and introduced in the Mediterranean, they are considered major invasive species (Hulme 2004). They form monospecific carpets (Sintes et al. 2007) and spread over open areas, such as rocky coastlines, matorrals and dunes (Au 2000; Suehs et al. 2004a; Vilà et al. 2006; Traveset et al. 2008), attaining near-dominance through their fast clonal growth, high genetic diversity, multiple reproduction strategies and competitiveness (Suehs et al. 2004b; Suehs et al. 2004a; Roiloa et al. 2009; Roiloa et al. 2014). Numerous studies have shown major effects of these plant species on the native plant and animal species, and on soil characteristics (D'Antonio \& Mahall 1991; D'Antonio 1993; Suehs et al. 2001; Palmer et al. 2004; Moragues \& Traveset 2005; Vilà et al. 2006; Orgeas et al. 2007; Galán 2008; Conser \& Connor 2009; Peña et al. 2010; Zedda et al. 2010; Affre 2011; Santoro et al. 2011; Novoa et al. 2013; Novoa \& González 2014). Carpobrotus management (eradication and control) could therefore be used to promote native communities, particularly in protected areas (Andreu et al. 2010; Ruffino et al. 2015). Removing living biomass will stop vegetative growth and open gaps for other plants to colonize (Andreu et al. 2010). Carpobrotus branches and leaves decompose slowly and form a thick litter (Conser \& Connor 2009) that can be left on site or removed. If the litter is left on site, germination will occur from the seeds contained in it; although the litter retains the seeds of native species, as much as $77.6 \%$ of the seeds are Carpobrotus (Chenot et al. 2014). Moreover, the litter releases allelopathic compounds thus leaving it on site would hamper the germination of native species (Novoa et al. 2012). If both living Carpobrotus and its litter are removed, germination will occur from the soil seed bank. However, with no litter remaining, there is a good chance that these seeds would be lost to soil erosion, mainly occurring with autumn heavy rains. Because Carpobrotus was often planted to reduce soil erosion in the first place, the suppression of its dense canopy can increase the impact of rain drops on an unstable soil structure then favoring the displacement of soil particles and seeds. The risks and impacts of extensive soil loss should always be evaluated prior to the eradication of both live-mats and litter in any restoration scenario.

The aim of the present study is to compare different treatments in order to guide the selection of future management modalities for Carpobrotus species invasion in a strict nature reserve. Different removal methods were compared, based on the following three objectives: i) limiting soil erosion, ii) limiting Carpobrotus recolonization and iii) favoring native vegetation recolonization. Four treatments were thus tested: (1) living Carpobrotus removal; (2) living Carpobrotus and litter removal; (3) Carpobrotus presence (control) and (4) native vegetation (reference). 


\section{Material and Methods}

\section{Study area}

Bagaud Island, a strict nature reserve since 2007, is part of Port-Cros National Park (south-

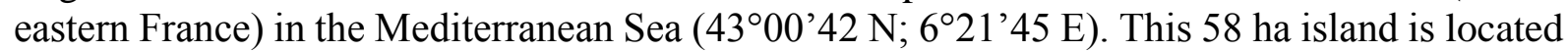
$7.5 \mathrm{~km}$ from the mainland shore and exhibits a low relief (maximum elevation at $57 \mathrm{~m}$ ). The climate on Bagaud Island is characterized by mild winters and a high relative air humidity $(81 \%$ / year) that persists into the summer. The annual average temperature is about $15^{\circ} \mathrm{C}$ with daily maximum summer often exceeding $30^{\circ} \mathrm{C}$. The average temperature of the coldest month is above $9^{\circ} \mathrm{C}$ (Krebs et al. 2015). The native vegetation of the island is dominated by matorral, i.e. shrublands found in regions with a Mediterranean climate. Other vegetation types include oak woodlands, halo-resistant coastal plant communities on the coast, and more or less halonitrophilous grassland patches with a mix of annual and perennial plant species (Krebs et al. 2015).

\section{Carpobrotus invasion}

Carpobrotus edulis (L.) N. E. Br. and Carpobrotus affine acinaciformis (Suehs et al. 2004a,b, 2006) were introduced to Bagaud Island intentionally in the mid-19th century to stabilize the embankments that were created during military fort construction. Both species are grouped under the term Carpobrotus thereafter. All are succulent chamaephytes with a slightly ligneous base. They grow prostrated on the ground, rooting at nodes and forming large, dense mats. Their invasiveness depends on characteristics typical of invasive plant species, such as (i) a lack of efficient pathogens in their new geographical range (i.e. Enemy Release Hypothesis: Williamson 1996; Keane \& Crawley 2002), (ii) a high clonal and genetic diversity, (iii) vigorous and fast clonal growth, (iv) several sexual reproduction strategies, (v) high and recurrent frequencies of introgression and hybridization, or (vi) seed and fruit dispersion by endozoochory (Suehs et al. 2001, 2004a, 2005, 2006; Bourgeois et al. 2005). Like elsewhere in the world, they have locally caused (i) a decrease in the species richness and diversity of rare and endemic plants; (ii) changes in soil chemistry; and (iii) a decrease in pollinator visits to native plants (Suehs et al. 2004b; Affre 2011).

\section{Experimental eradication design and sampling}

The experiment was set up on Bagaud Island in July 2010 and monitored in November 2010 and April 2011. The four sites were located between 10 and $600 \mathrm{~m}$ from the coast, and between 10 and $40 \mathrm{~m}$ of altitude (the two sites the most distant to each other were $1 \mathrm{~km}$ away while the two closest were less than $100 \mathrm{~m}$ away). Each of the study sites is composed of a native vegetation area, bordering a patch of Carpobrotus. On each site, three replicate blocks were established, each consisting of four treatments implemented in one $2 \mathrm{~m} \times 2 \mathrm{~m}$ quadrat each (4 quadrats / block and 3 replicate blocks / site; Figure 1a). In each replicate block, a first quadrat serving as reference state was placed in native vegetation. Within the patch of Carpobrotus, three quadrats with the following treatments were defined: (1) living Carpobrotus manual removal, consisting in pulling living Carpobrotus stems with their roots; (2) living Carpobrotus and litter removal; (3) Carpobrotus presence (control) and (4) native vegetation (reference). Removal took place at the end of June 2010 (Figure 1a). Such manual removal of Carpobrotus is feasible at larger scales: it requires 52 man-days to remove 1 ha if uprooted Carpobrotus material is left and composted in piles on site (Ruffino et al. 2015). 
To measure soil erosion after applying the various treatments, monitoring was established by implanting plastic boxes downhill from the quadrats in order to collect eroded soil over a period of nine months. This could not be done in native vegetation, because this would have required the destruction of small patches of native vegetation, and this is forbidden in a strict nature reserve. Boxes were thus only placed in Carpobrotus patches where soil depth was equal to or greater than that of the plastic boxes $(19.1 \mathrm{~cm})$. In July 2010, two plastic boxes ( $78 \times \mathrm{W}$ $25 \times \mathrm{H} 19.1 \mathrm{~cm})$ were positioned in trenches dug downhill from each quadrat. For each treatment, one plastic box was placed directly below the quadrat, and another was placed behind a $50 \mathrm{~cm}$-wide Carpobrotus strip to see if the strip would limit soil erosion (Figure 1b). The plastic boxes were collected in November 2010 and April 2011 and soil samples were dried and weighed. ). The total number of boxes was 35: 11 in living Carpobrotus removal (6 upper boxes and 5 lower boxes), 12 in living Carpobrotus and litter removal (6 each in upper and lower boxes), 12 in Carpobrotus presence (6 each in upper and lower boxes).

The composition of plant communities was studied before (April 2010) and after (April 2011) treatment application on all quadrats. In each $2 \mathrm{~m} \times 2 \mathrm{~m}$ treatment quadrat, the percent cover of each species was visually assessed in a centered $1 \mathrm{~m}^{2}$ quadrat in order to avoid border effects. We also visually estimated the total percent cover of vegetation, the percent cover of native species and Carpobrotus.

\section{Data analysis}

Analyses were performed using the program R ( $\mathrm{R}$ Core Team 2014) and made use of the following R packages: "coin" (Zeileis et al. 2008), and "vegan" (Oksanen et al. 2013).

The effects of the treatments on soil erosion were analyzed using a permutation test (Zeileis et al. 2008). Permutation tests are a modern and powerful type of statistical significance test in which the population distribution is obtained by calculating the sample statistics under every possible permutation of the observed data points, and such tests are appropriate for small sample sizes. The p-values for the multiple comparison tests were recalculated with the BH adjustment (Benjamini \& Hochberg 1995). This test was run on the weight of soil depending on the treatments (Carpobrotus removal, Carpobrotus and litter removal, Carpobrotus presence) and on the position of the box (upper box, lower box).

To study the effects of the treatments on plant recolonization, permutation tests were run on i) total plant cover, ii) Carpobrotus plant cover, iii) native plant cover and iv) species richness, depending on the treatments. Treatments were compared to the Carpobrotus presence and the native vegetation treatments.

In order to study the composition of the vegetation before and after applying the treatments, a NMDS (Non-Metric Multidimensional Scaling) analysis (Borcard et al. 2011) was run on plant species percent covers of spring 2010 and spring 2011 ( 81 samples $\times 47$ species; $\mathrm{N}=12$ for most treatment/year combinations except for Carpobrotus removal in $2011 \mathrm{~N}=11$ and Carpobrotus and litter removal in $2011 \mathrm{~N}=10$ ). This analysis was followed by a Multiple Response Permutation Procedure analysis (MRPP) to determine the statistical significance of the differences between years and between treatments.

\section{Results}

\section{Treatment effects on soil erosion}

The removal of Carpobrotus and its litter led to a soil erosion 4.5 to 23 times higher $(665.5 \mathrm{~g}$ on average / upper box or 3.33 tons/ha) than other combinations of treatments: removing Carpobrotus alone (53.0 g or 0.27 ton/ha) or leaving Carpobrotus in place (control, $69.8 \mathrm{~g}$ or 
$0.35 \mathrm{ton} / \mathrm{ha})(\operatorname{maxT}=4.07, \mathrm{p}$-value $=0.001 ;$ Figure 2$)$. Leaving a 50-cm strip of Carpobrotus downhill from where Carpobrotus and its litter were removed significantly prevented eroded soil from leaving the area by a factor of 4.5 (148.7 $\mathrm{g}$ on average / lower box for this treatment vs. $665.5 \mathrm{~g}$ on average / upper box; Figure 2).

\section{Treatment effects on plant percent cover and species richness}

Total vegetation cover 10 months after the treatments were applied was significantly lower where Carpobrotus had been removed, regardless of whether the litter was also removed or not, intermediate on the Carpobrotus presence treatment and highest in the native vegetation (maxT $=4.85$, p-value $<0.001$; Figure 3 ). Native vegetation cover was significantly higher in the native vegetation quadrats and lower for the other treatments $(\operatorname{maxT}=6.42, \mathrm{p}$-value $<0.001$; Figure 3). Carpobrotus cover was significantly higher in the control and lower in the other treatments $(\operatorname{maxT}=6.55, \mathrm{p}$-value $<0.001$; Figure 3$)$. Finally, species richness was highest in the native vegetation, intermediate where Carpobrotus had been removed without removing the litter and lowest in the Carpobrotus presence treatment and where Carpobrotus and its litter were removed $(\operatorname{maxT}=3.16, \mathrm{p}$-value $<0.009$; Figure 3$)$.

\section{Treatment effects on plant communities}

The NMDS analysis on the vegetation (stress: 0.12) and the Multiple Response Permutation Procedure analysis (MRPP) showed a significant difference between some combinations of treatments and years (observed delta: 0.34; expected delta: 0.68; p-value<0.001). As shown in Figure 4, axis 1 delineated the quadrats sampled in the native vegetation, characterized by Pinus halepensis, Pistacia lentiscus and Rosmarinus officinalis, from the other quadrats. Axis 2 separated the control quadrats and the quadrats sampled before Carpobrotus removal, characterized by Carpobrotus, from quadrats where Carpobrotus was removed with and without its litter. The latter is characterized by Geranium ssp. and Sonchus asper, while quadrats where Carpobrotus and its litter were removed are characterized by Frankenia hirsuta and Sonchus asper glaucescens.

\section{Discussion}

Interestingly, our experimental eradication study shows that, when comparing the two removal methods (i.e. living Carpobrotus removal or living Carpobrotus and litter removal) leaving Carpobrotus litter on site limits soil erosion and leads to higher native plant species recolonization but also to higher reinvasion potential.

Ten months after applying the treatments, Carpobrotus removal (whether the litter is removed or not) obviously leads to a large decrease in Carpobrotus cover compared to quadrats where it is left in place, although some germinations of Carpobrotus can be observed. Recolonization of native vegetation is scarce, although a slightly higher species richness of native vegetation can be observed on these quadrats relative to the invaded ones or even to the same quadrats prior to removal. Colonization of these open areas begins with resprouting species, such as Aetheoriza bulbosa, and Arisarum vulgare. This is followed by the species that either have large seed banks (Frankenia hirsuta and Lotus cytisoides) or employ longdistance dispersals (Sonchus asper asper and Sonchus asper glaucescens) (Krebs et al. 2015). Most of the colonizing species are coastal (e.g. Atriplex prostrata, Frankenia hirsuta, Lotus cytisoides, Senecio leucanthemifolius and Sonchus asper glaucescens) and early matorral succession (e.g. Aetheoriza bulbosa, Arisarum vulgare, Senecio cineraria) species; very few 
opportunistic or weedy species are recorded, and when found, their percent covers are low (e.g. Sonchus asper asper and Solanum nigrum).

The recovery rate of native plants following Carpobrotus removal will depend on the life and growth forms, and dispersal abilities of native plants: on Bagaud Island, pioneer species colonize quickly, because the invaded areas are relatively small (consisting of only about 1 ha in each case) and are surrounded by native vegetation that can serve as an source for seeds: Aetheoriza bulbosa, Crithmum maritimum, Euphorbia pithyusa, Frankenia hirsuta, Lotus cytisoides, Sonchus asper glaucescens, are therefore found early on (Krebs et al. 2015). In addition, the increase in soil temperature and light following invasive plant removal favor the annual species germination (D'Antonio and Meyerson 2002; Andreu et al. 2010), such as Atriplex prostrata, Bromus sp., Catapodium marinum, Poa annua, Polycarpon tetraphyllum, Rostraria cristata, Spergularia sp. (Krebs et al. 2015). In time, the full development of a low matorral plant community will become dominated by relatively slow-growth woody species (D’Antonio \& Meyerson 2002), such as Pistacia lentiscus, etc. (Krebs et al. 2015).

Removing the litter from the ground along with the live parts of Carpobrotus leads to major soil erosion most likely due to increased rain splash and runoff-driven erosion processes. The soil was almost completely bare during the autumn and winter following the removal, apart from a few germinations of Carpobrotus and Lotus cytisoides and a few resprouts of Aetheoriza bulbosa and Arisarum vulgare. The soil is therefore highly sensitive to the erosion induced by autumn and winter precipitation. Similar increases in runoff and erosion rates were observed by Zavala et al. (2009) when the charred litter from a prescribed fire was removed and the bare soil was exposed to simulated rainfall. The water repellency of sandy soil after a long period of Carpobrotus presence has also been observed (pers. obs.). Sowing seeds of native species can be considered to accelerate native plant colonization but does not counteract soil erosion. Sown species require the autumn rain to germinate, and this means that the native plants would only appear as germinating seedlings, which are too young and small to provide much erosionpreventing benefit at a time of year when erosion control is needed the most (pers. obs.).

On other hand, this study clearly demonstrates that leaving a $50 \mathrm{~cm}$ strip of Carpobrotus downhill from the areas where Carpobrotus and its litter are removed, serves to significantly reduce the amount of soil exported from that area, to the point that it becomes comparable to areas where Carpobrotus was left in place. A Carpobrotus strip can therefore be left in place for a couple of years while waiting for native species to colonize and cover the soil, and must be removed once native colonization has taken place in order to avoid re-invasion. If such an option is taken, funding and capacity must be allocated i) for Carpobrotus strip management while it is in place and ii) for its later removal. Site managers have to make sure that the Carpobrotus strip is not a source of seeds and re-colonization while it is in place: cutting all the flowers as they appear to prevent seed production and trimming the strip edge if it grows too quickly. To further mitigate soil loss by runoff, another option would be to cover bare ground with geotextile on the steeper areas and/or on the edges of patches where Carpobrotus and its litter have been removed (Bhattacharyya et al. 2010). In case native seeds are sowed, this should most probably be combined with a way to prevent seeds from being washed away by the first heavy rains, before they germinate: it may include geotextile or seed burying or drilling, but would have to be investigated (Bochet et al. 2010; Álvarez-Mozos et al. 2014).

Novoa and co-workers (Novoa et al. 2012, 2013) have shown that Carpobrotus edulis produces allelopathic substances that accumulate in the litter and prevent seed germination, thus potentially limiting native and exotic plant reestablishment. They therefore advise against leaving fresh or dry Carpobrotus litter on restored areas. By contrast, we have found that species richness and native vegetation percent cover actually increase slightly when Carpobrotus is removed and its litter remains. Our results are however not significant and 
different from the seed bank study that was carried out at the same site (Chenot et al. 2014). These differences may result from the short time span of our study.

If the litter is left on site, colonization will occur from the seeds contained in Carpobrotus litter, some of which come from native species (22.4\%), such as Atriplex prostrata, Frankenia hirsuta and Sonchus asper. However, most of the seeds (77.6\%) are Carpobrotus (Chenot et al. 2014). Although selecting the treatment which leaves the litter on the ground is less complicated and less expensive to implement, subsequent control of Carpobrotus germinations and resprouts may actually be more intensive. In the soil seed bank, Carpobrotus is also present, but native species seeds are more abundant (62.4\% vs. $37.6 \%$ for Carpobrotus) than in the litter (see Chenot et al., 2014 for list of species).

The risk of reinvasion from a site where an invasive species has been removed is lower on uninhabited islands or on islands managed for biodiversity conservation sake, such as Bagaud Island (Ruffino et al. 2015). The chance of reinvasion and spread is expected to be reduced once Mediterranean mattoral native plants, forming dense stands, have re-established (Ruffino et al. 2015). Therefore, once the native vegetation has recolonized the environment, and in the absence of further disturbances, one of the expected results is a lack of Carpobrotus germination in the newly established native vegetation understory. Indeed, the study of Chenot et al. (2014) showed that Carpobrotus seeds were found in significant quantities within the native seed bank on Bagaud Island, even though Carpobrotus was not expressed in the aboveground vegetation.

However, Carpobrotus have consequent long-term seed banks (at least up to 5 years) and can also resprout many years after removal (up to 8 years) from underground stems and can thus quickly reinvade (Affre 2011; Ruffino et al. 2015). Successful eradications of such plant species thus requires regular and long-term controls of treated areas (Mack and Lonsdale 2011); on Bagaud Island, 45 man-days / ha were necessary to remove Carpobrotus germinations and resprouts one year after large scale removal (2012; Ruffino et al. 2015). Therefore, sufficient funding and capacity have to be planned before the management program is implemented, to monitor the treated areas in the long-term and to take necessary actions (germination or resprout removal) to ensure the ultimate success of the eradication.

\section{Acknowledgements}

This study was made possible through the major support of Port-Cros National Park, the Institut Méditerranéen de Biodiversité et d'Ecologie (IMBE) and funding partners (the European Union FEDER, Conservatoire du littoral et des rivages lacustres, Fondation Total, Parc National de Port Cros). We thank the staff at Port-Cros National Park, Eric Vidal and Frédéric Médail (IMBE) for their commitment and logistic support. We also thank all the people who helped with our field work, in particular Teddy Baumberger, Noellie Fonvieille and Renaud Jaunatre for removing Carpobrotus from our quadrats, Alain Bence, Solène Masson and Isabelle Muller for collecting the soil from the boxes, and Daniel Pavon, who provided assistance in identifying plants. We also thank Kolo D. Wamba from Proediting who revised the English.

\section{References}

Affre L (2011) Ecological and Evolutionary Insights from Plant Invasions: The Case of Carpobrotus spp. (Aizoaceae) in the Mediterranean Basin. Pages 1-40 In: Berhardt LV (eds) Advances in Medicine and Biology. Nova Science Publishers. Hauppauge, NY, USA 
Álvarez-Mozos J, Abad E, Goñi M, Giménez R, Campo MA, Díez J, Casalí J, Arive M, Diego I (2014) Evaluation of erosion control geotextiles on steep slopes. Part 2: Influence on the establishment and growth of vegetation. CATENA 121:195-203

Andreu J, Manzano-Piedras E, Bartomeus I, Dana ED, Vilà M (2010) Vegetation Response after Removal of the Invasive Carpobrotus Hybrid Complex in Andalucía, Spain. Ecological Restoration 28:440-448. doi: 10.3368/er.28.4.440

Au L (2000) Carpobrotus edulis in Coastal California Plant Communities. Restoration and Reclamation Review 6:1-7

Benjamini Y, Hochberg Y (1995) Controlling the False Discovery Rate: A Practical and Powerful Approach to Multiple Testing. Journal of the Royal Statistical Society. Series B (Methodological) 57:289-300

Berglund H, Järemo J, Bengtsson G, Coulson AET, Whitlock EMC (2009) Endemism Predicts Intrinsic Vulnerability to Nonindigenous Species on Islands. American Naturalist 174:94-101

Bhattacharyya R, Fullen MA, Davies K, Booth CA (2010) Use of palm-mat geotextiles for rainsplash erosion control. Geomorphology 119:52-61

Bochet E, García-Fayos P, Tormo J (2010) How can we control erosion of roadslopes in semiarid Mediterranean areas? Soil improvement and native plant establishment. Land Degradation \& Development 21:110-121

Borcard D, Gillet F, Legendre P (2011) Numerical Ecology with R. Springer New York, New York, NY

Born W, Rauschmayer F, Bräuer I (2005) Economic evaluation of biological invasions - a survey. Ecological Economics 55:321-336

Bourgeois K, Suehs CM, Vidal E, Médail F (2005) Invasional meltdown potential: Facilitation between introduced plants and mammals on French Mediterranean islands. Ecoscience 12:248-256. doi: 10.2980/11195-6860-12-2-248.1

Cacho JO, Spring D, Pheloung P, Hester S (2006) Evaluating the Feasibility of Eradicating an Invasion. Biological Invasions 8:903-917

Chenot J, Affre L, Passetti A, Buisson E (2014) Consequences of iceplant (Carpobrotus) invasion on the vegetation and seed bank structure on a Mediterranean island: response elements for their local eradication. Acta Botanica Gallica 161:301-308

Conser C, Connor EF (2009) Assessing the residual effects of Carpobrotus edulis invasion, implications for restoration. Biological Invasions 11:349-358

Courchamp F, Caut S, Bonnaud E, Bourgeois K, Angulo E, Watari Y (2011) Eradication of alien invasive species: surprise effects and conservation successes. Pages 285-289 In: Veitch CR, Towns DR (eds) Island invasives: eradication and management. IUCN, Gland, Switzerland

Courchamp F, Chapuis J-L, Pascal M (2003) Mammal invaders on islands: impact, control and control impact. Biological Review 78:347-383

Cronk QCB (1997) Islands: stability, diversity, conservation. Biodiversity \& Conservation 6:477-493

D'Antonio C, Meyerson LA (2002) Exotic Plant Species as Problems and Solutions in Ecological Restoration: A Synthesis. Restoration Ecology 10:703-713

D'Antonio CM (1993) Mechanisms Controlling Invasion of Coastal Plant Communities by the Alien Succulent Carpobrotus edulis. Ecology 74:83-95

D'Antonio CM, Haubensak K (1998) Community and ecosystem impacts of introduced species in California. Fremontia 26:16-18

D'Antonio CM, Mahall BE (1991) Root Profiles and Competition between the Invasive, Exotic Perennial, Carpobrotus edulis, and Two Native Shrub Species in California Coastal Scrub. American Journal of Botany 78:885-894 
Denslow JS (2001) The ecology of insular biotas. Trends Ecology \& Evolution 16:423-424

Drake DR, Mulder CPH, Towns DR, Daugherty CH (2002) The biology of insularity: an introduction. Journal of Biogeography 29:563-569

Galán P (2008) Efecto de la planta invasora Carpobrotus edulis sobre la densidad del eslizón tridáctilo (Chalcides striatus) en una localidad costera de Galicia. Boletín de la Asociación Herpetológica Española 19:117-121

Gratton C, Denno RF (2006) Arthropod Food Web Restoration Following Removal Of An Invasive Wetland Plant. Ecological Applications 16:622-631

Hulme PE (2004) Islands, invasions and impacts: a Mediterranean perspective. Pages 359-383 In: Fernández-Palacios JM, Morici S (eds) Ecologia insular / Island Ecology. Cabildo Insular de la Palma, Asociaciòn Española de Ecologia Terrestre (AEET).

Keane RM, Crawley MJ (2002) Exotic plant invasions and the enemy release hypothesis. Tree 17:164-170.

Krebs E, Affre L, Aboucaya A, Allègre A, Chenot J, Montegu C, Passetti A, Pavon D, Buisson É (2015) Résilience de la flore indigène après éradication des griffes de sorcière (Carpobrotus sp.) sur une île méditerranéenne. Revue Ecologie Terre et Vie 70:80-90

Loope L, Sheppard A, Pascal M, Jourdan H (2006) L'éradication: une mesure de gestion des populations allochtones. Pages 401-417 In: Beauvais ML, Coléno A, Jourdan H, Chouchan D. Les espèces envahissantes dans l'archipel néo-calédonien. IRD, Paris, France

Mack RN, Lonsdale WM (2011) Eradicating invasive plants: hard-won lessons for islands. Pages 164-172 In: Veitch CR, Towns DR (eds) Island invasives: eradication and management. IUCN, Gland, Switzerland

Mack RN, Simberloff D, Mark Lonsdale W, Evans H, Clout M, Bazzaz FA (2000) Biotic Invasions: Causes, Epidemiology, Global Consequences, and Control. Ecological Applications 10:689-710

Marchante E, Kjøller A, Struwe S, Freitas H (2008) Short- and long-term impacts of Acacia longifolia invasion on the belowground processes of a Mediterranean coastal dune ecosystem. Applied Soil Ecology 40:210-217

McKinney ML, Lockwood JL (1999) Biotic homogenization: a few winners replacing many losers in the next mass extinction. Trends in Ecology and Evolution 14:450-453

Médail F, Affre L, Suehs C (2004) Carpobrotus sp. C. edulis (L.) N.E. Br. \& C. aff. acinaciformis (L.) L. Bolus. Les griffes de sorcières. Pages 52-55 In: Muller S, Aboucaya A (eds) Plantes invasives en France: état des connaissances et propositions d'actions. Muséum national d'histoire naturelle, Paris, France

Milbau A, Stout JC (2008) Factors Associated with Alien Plants Transitioning from Casual, to Naturalized, to Invasive. Conservation Biology 22:308-317

Mooney HA, Cleland EE (2001) The evolutionary impact of invasive species. Proceedings National Academy of Science 98:5446-5451. doi: 10.1073/pnas.091093398

Moragues E, Traveset A (2005) Effect of Carpobrotus spp. on the pollination success of native plant species of the Balearic Islands. Biological Conservation 122:611-619. doi: 10.1016/j.biocon.2004.09.015

Novoa A, González L (2014) Impacts of Carpobrotus edulis (L.) N.E.Br. on the Germination, Establishment and Survival of Native Plants: A Clue for Assessing Its Competitive Strength. PLOS ONE 9:e107557. doi: 10.1371/journal.pone.0107557

Novoa A, González L, Moravcová L, Pyšek P (2012) Effects of Soil Characteristics, Allelopathy and Frugivory on Establishment of the Invasive Plant Carpobrotus edulis and a Co-Occuring Native, Malcolmia littorea. PLoS ONE 7:e53166. doi: 10.1371/journal.pone.0053166 
Novoa A, González L, Moravcová L, Pyšek P (2013) Constraints to native plant species establishment in coastal dune communities invaded by Carpobrotus edulis: Implications for restoration. Biological Conservation 164:1-9. doi: 10.1016/j.biocon.2013.04.008

Nunn PD (1994) Oceanic Islands. Blackwell

Oksanen J et al. (2013) Package 'vegan'. Community ecology package, version 2. http://cran.ism.ac.jp/web/packages/vegan/vegan.pdf

Orgeas J, Ponel P, Fadda S, Matocq A, Turpaud A (2007) Conséquences écologiques de l'envahissement des griffes de sorcière (Carpobrotus spp.) sur les communautés d'insectes d'un îlot du Parc national de Port-Cros (Var). Scientific Reports of Port-Cros National Park 22:233-257

Palmer M, Linde M, Pons GX (2004) Correlational patterns between invertebrate species composition and the presence of an invasive plant. Acta Oecologica 26:219-226

Peña E de la, Clercq N de, Bonte D, Roiloa S, Rodríguez-Echeverría S, Freitas H (2010) Plantsoil feedback as a mechanism of invasion by Carpobrotus edulis. Biological Invasions 12:3637-3648

R Core Team (2014) R: A Language and Environment for Statistical Computing. R Foundation for Statistical Computing, Vienna, Austria

Richardson DM, Pyšek P, Rejmánek M, Barbour MG, Panetta FD, West CJ (2000) Naturalization and invasion of alien plants: concepts and definitions. Diversity \& Distribution 6:93-107

Ricketts TH, Dinerstein E, Boucher T, Brooks TM, Butchart SHM, Hoffmann M, Lamoreux JF, Morrison J, Parr M, Pilgrim JD, Rodrigues ASL, Sechrest W, Wallace GE, Berlin K, Bielby J, Burgess ND, Church DR, Cox N, Knox D, Loucks C, Luck GW, Master LL, Moore R, Naidoo R, Ridgely R, Schatz GE, Shire G, Strand H, Wettengel W, Wikramanayake E (2005) Pinpointing and preventing imminent extinctions. Proceedings National Academy of Science USA 102:18497-18501

Roiloa SR, Rodríguez-Echeverría S, Freitas H (2014) Effect of physiological integration in self/non-self genotype recognition on the clonal invader Carpobrotus edulis. J Plant Ecol 7:413-418. doi: 10.1093/jpe/rtt045

Ruffino L, Krebs E, Passetti A, Aboucaya A, Affre L, Fourcy D, Lorvelec O, Barcelo A, Berville L, Bigeard N, Brousset L, Méringo HD, Gillet P, Quilliec PL, Limouzin Y, Médail F, Meunier J-Y, Pascal M, Pascal M, Ponel P, Rifflet F, Santelli C, Buisson E, Vidal E (2015) Eradications as scientific experiments: progress in simultaneous eradications of two major invasive taxa from a Mediterranean island. Pest Management Science 71:189-198

Santoro R, Jucker T, Carranza M, Acosta A (2011) Assessing the effects of Carpobrotus invasion on coastal dune soils. Does the nature of the invaded habitat matter? Community Ecology 12:234-240

Saunders A, Denny C (2005) The Cooperative Islands Initiative: "turning back the tide of invasions". Pages 211-214 In: Brunel S (eds) Invasive Plants in Mediterranean Type Regions of the World / Plantes envahissantes dans les régions méditerranéennes du monde. Council of Europe Publishing, Mèze, France

Sax DF, Gaines SD (2008) Species invasions and extinction: The future of native biodiversity on islands. Proceedings National Academy of Science 105:11490-11497

Sax DF, Gaines SD, Brown JH, Doak AEDF (2002) Species Invasions Exceed Extinctions on Islands Worldwide: A Comparative Study of Plants and Birds. American Naturalist 160:766-783

Simberloff D, Martin J-L, Genovesi P, Maris V, Wardle DA, Aronson J, Courchamp F, Galil B, García-Berthou E, Pascal M, Pyšek P, Sousa R, Tabacchi E, Vilà M (2013) Impacts of 
biological invasions: what's what and the way forward. Trends in Ecology \& Evolution 28:58-66

Sintes T, Moragues E, Traveset A, Rita J (2007) Clonal growth dynamics of the invasive Carpobrotus affine acinaciformis in Mediterranean coastal systems: A non-linear model. Ecological Modelling 206:110-118

Suehs C, Médail F, Affre L (2001) Ecological and genetic features of the invasion by the alien Carpobrotus plants in Mediterranean island habitats. Pages 145-158 In: Brundu G, Brock J, Camarda I, Child J, Wade M (eds) Plant invasions: species ecology and ecosystem management. Backhuys, Leiden, The Netherlands

Suehs CM, Affre L, Médail F (2004a) Invasion dynamics of two alien Carpobrotus (Aizoaceae) taxa on a Mediterranean island: II. Reproductive strategies. Heredity 92:550-556

Suehs CM, Affre L, Médail F (2004b) Invasion dynamics of two alien Carpobrotus (Aizoaceae) taxa on a Mediterranean island: I. Genetic diversity and introgression. Heredity 92:31-40

Suehs CM, Affre L, Médail F (2005) Unexpected insularity effects in invasive plant mating systems: the case of Carpobrotus (Aizoaceae) taxa in the Mediterranean Basin. Biological Journal of the Linnean Society 85:65-79

Suehs CM, Charpentier S, Affre L, Médail F (2006) The evolutionary potential of invasive Carpobrotus (Aizoaceae) taxa: are pollen-mediated gene flow potential and hybrid vigor levels connected? Evolutionary Ecology 20:447-463

Traveset A, Moragues E, Valladares F (2008) Spreading of the invasive Carpobrotus aff. acinaciformis in Mediterranean ecosystems: The advantage of performing in different light environments. Applied Vegetation Science 11:45-54

Trevino HS, Skibiel AL, Karels TJ, Dobson FS (2007) Threats to Avifauna on Oceanic Islands. Conservation Biology 21:125-132

van Kleunen M, Dawson W, Essl F, Pergl J, Winter M, Weber E, Kreft H, Weigelt P, Kartesz J, Nishino M, Antonova LA, Barcelona JF, Cabezas FJ, Cárdenas D, Cárdenas-Toro J, Castaño N, Chacón E, Chatelain C, Ebel AL, Figueiredo E, Fuentes N, Groom QJ, Henderson L, Inderjit, Kupriyanov A, Masciadri S, Meerman J, Morozova O, Moser D, Nickrent DL, Patzelt A, Pelser PB, Baptiste MP, Poopath M, Schulze M, Seebens H, Shu W, Thomas J, Velayos M, Wieringa JJ, Pyšek P (2015) Global exchange and accumulation of non-native plants. Nature 525:100-103. doi: 10.1038/nature14910

Vilà M, Espinar JL, Hejda M, Hulme PE, Jarošík V, Maron JL, Pergl J, Schaffner U, Sun Y, Pyšek P (2011) Ecological impacts of invasive alien plants: a meta-analysis of their effects on species, communities and ecosystems. Ecology Letters 14:702-708

Vilà M, Tessier M, Suehs CM, Brundu G, Carta L, Galanidis A, Lambdon P, Manca M, Médail F, Moragues E, Traveset A, Troumbis AY, Hulme PE (2006) Local and regional assessments of the impacts of plant invaders on vegetation structure and soil properties of Mediterranean islands. Journal of Biogeography 33:853-861

Vitousek PM, D'Antonio CM, Loope LL, Westbrooks R (1996) Biological Invasions as Global Environmental Change. American Scientist 84:468-478

Whittaker RJ, Fernandez-Palacios JM (2007) Island Biogeography: Ecology, Evolution, and Conservation. OUP Oxford

Williamson M (1996) Biological Invasions. Chapman \& Hall

Zavala LM, Jordán A, Gil J, Bellinfante N, Pain C (2009) Intact ash and charred litter reduces susceptibility to rain splash erosion post-wildfire. Earth Surface Processes and Landforms 34:1522-1532

Zavaleta ES, Hobbs RJ, Mooney HA (2001) Viewing invasive species removal in a wholeecosystem context. Trends in Ecology \& Evolution 16:454-459 
Zedda L, Cogoni A, Flore F, Brundu G (2010) Impacts of alien plants and man-made disturbance on soil-growing bryophyte and lichen diversity in coastal areas of Sardinia (Italy). Plant Biosystems 144:547-562

Zeileis A, Wiel MA van de, Hornik K, Hothorn T (2008) Implementing a Class of Permutation Tests: The coin Package. Journal of Statistical Software 28:1-23 
Figure 1. A. Experimental eradication set-up in four sites on Bagaud Island. Four treatments regrouped in blocks were replicated three times. B. Position of the plastic boxes with respect to the $2 \mathrm{~m} \times 2 \mathrm{~m}$ experimental quadrat, to the $2 \mathrm{~m} \times 2 \mathrm{~m}$ vegetation monitoring quadrat and to the Carpobrotus strip.

Figure 2. Effects of the three treatments (1: Carpobrotus presence (control), 2: living Carpobrotus removal, 3: living Carpobrotus and litter removal) and of the position of the box downhill from the plots on soil erosion (in $\mathrm{g} / \mathrm{box})(\operatorname{maxT}=4.07$, p-value $=0.001)$. $*$ Upper boxes are placed directly below the quadrats while **lower boxes are placed below a $50 \mathrm{~cm}$ wide Carpobrotus strip (see Figure 1 for detailed set-up). Soil erosion monitoring could not be carried out on the fourth treatment (native vegetation - reference) because this would have required the destruction of small patches of native vegetation in a strict nature reserve. Error bars represent $\pm \mathrm{SE}$, bars having a common letter are not significantly different (multiple comparison tests recalculated with the $\mathrm{BH}$ adjustment; $\mathrm{p}>0.05$ ).

Figure 3. Effects of the four treatments (1: Carpobrotus presence (control), 2: living Carpobrotus removal, 3: living Carpobrotus and litter removal, 4: native vegetation (reference)) on the percent cover of total vegetation, Carpobrotus and native vegetation and on species richness $(\mathrm{N}=12)$. Error bars represent $\pm \mathrm{SE}$, bars having a common letter are not significantly different (multiple comparison tests recalculated with the BH adjustment; $\mathrm{p}>0.05$ ).

Figure 4. Non-Metric Multidimensional Scaling (NMDS) analysis of plant cover depending on treatments and year (81 samples $\times 47$ species) (NMDS stress: 0.12 ). For clarity-sake, only the most correlated species are shown. Samples are grouped by combinations of treatment and year and written in boxes. 
1 Figure 1

\section{A}

2010

2011

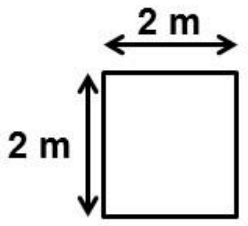

Carpobrotus

Carpobrotus

presence

presence

(control)

$\times 3$

blocks I

site

(4 sites

total)

Carpobrotus

presence

Carpobrotus

removal

Carpobrotus

Carpobrotus

presence and litter removal

native vegetation

native vegetation

(reference)

B

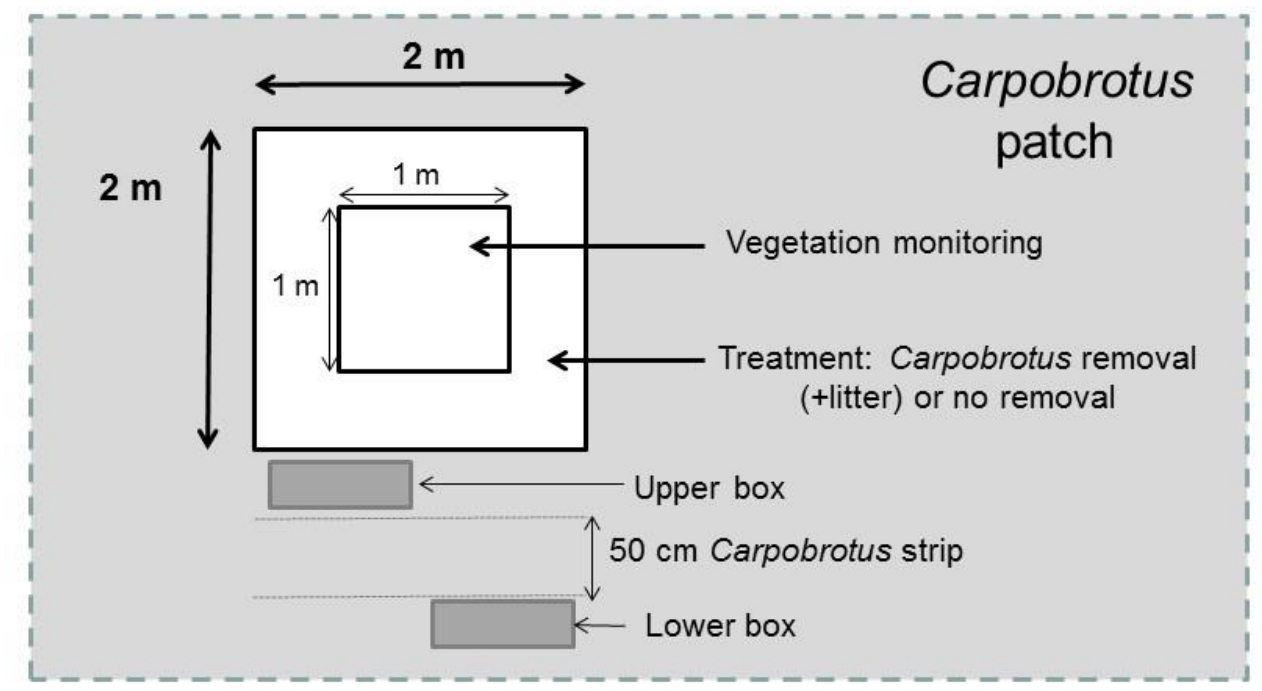

slope

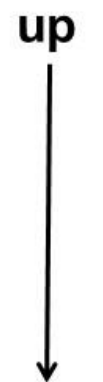

down

$5 \quad$ Figure 2 


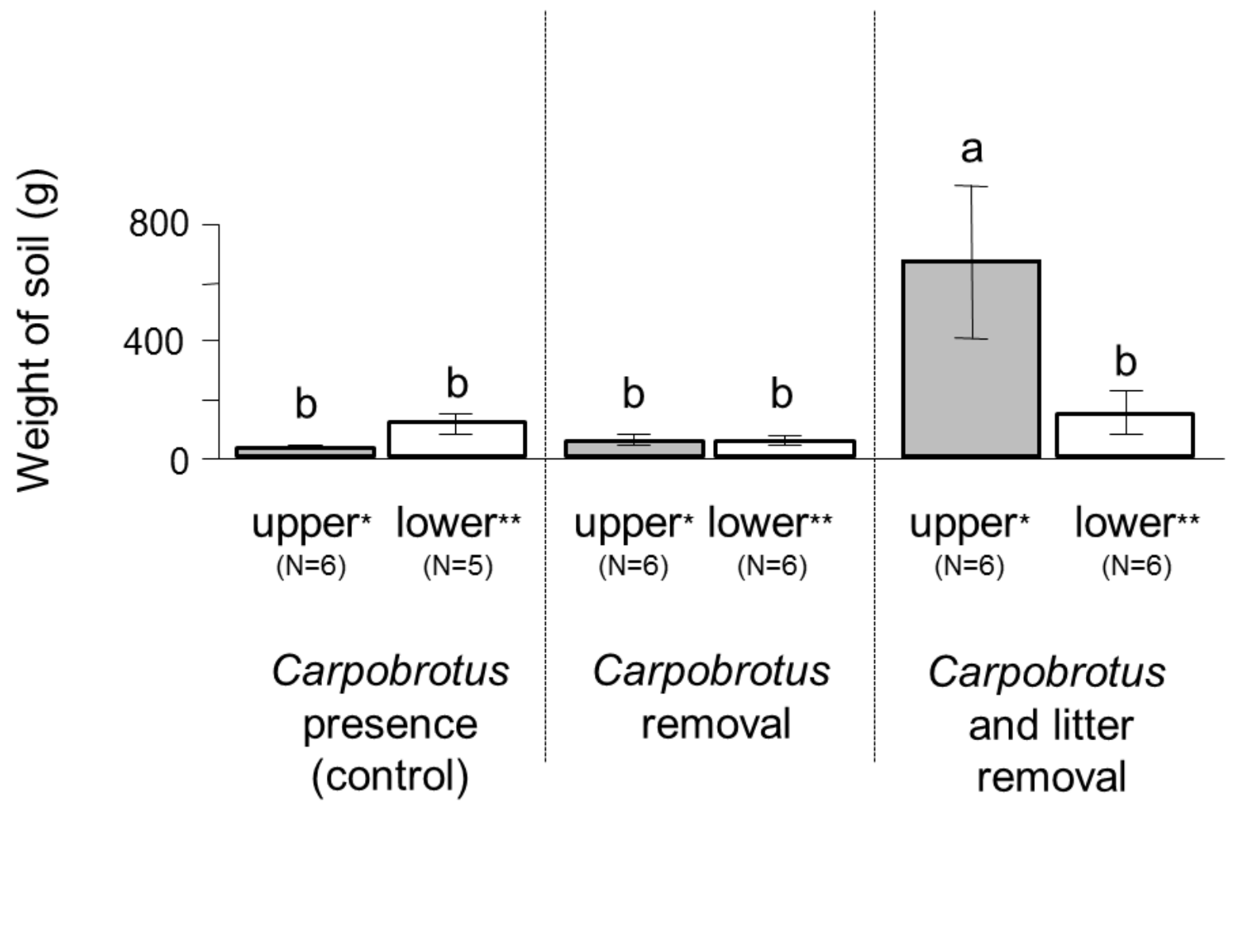


2 Figure 3
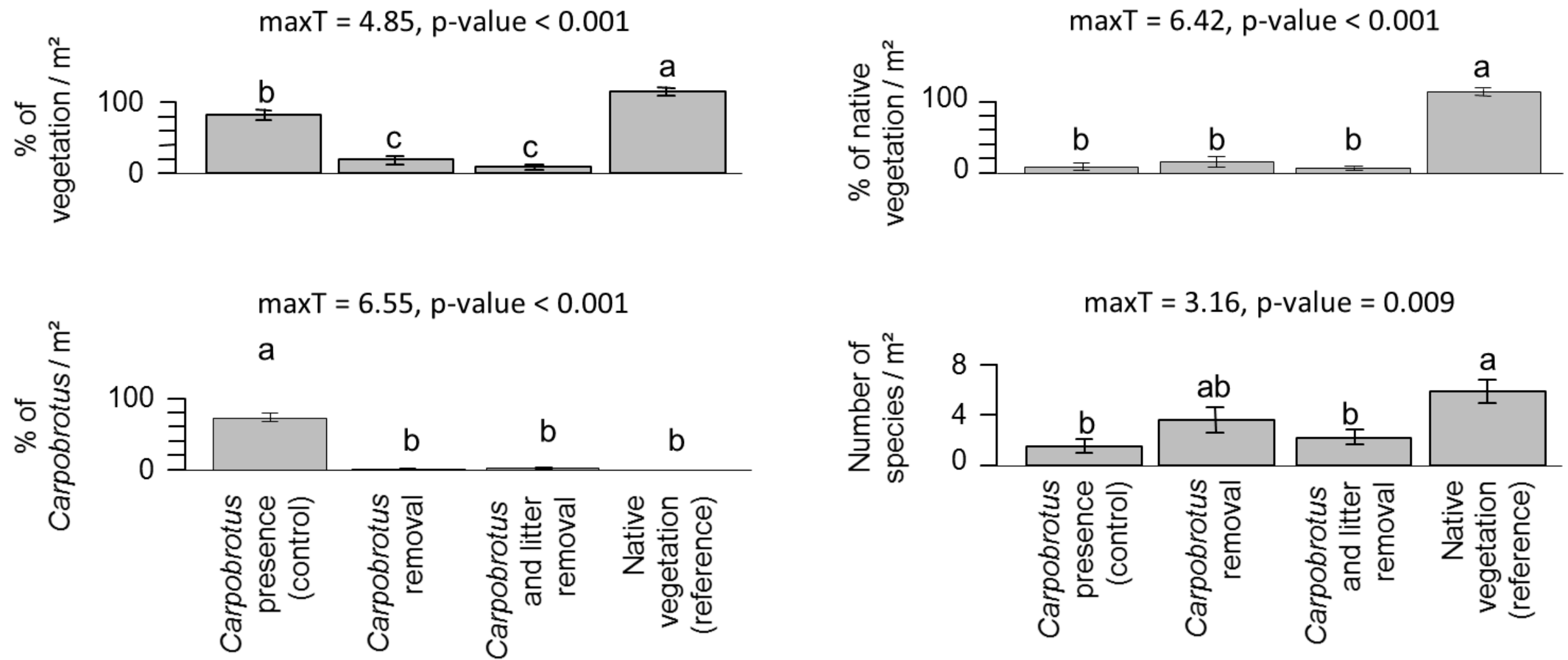


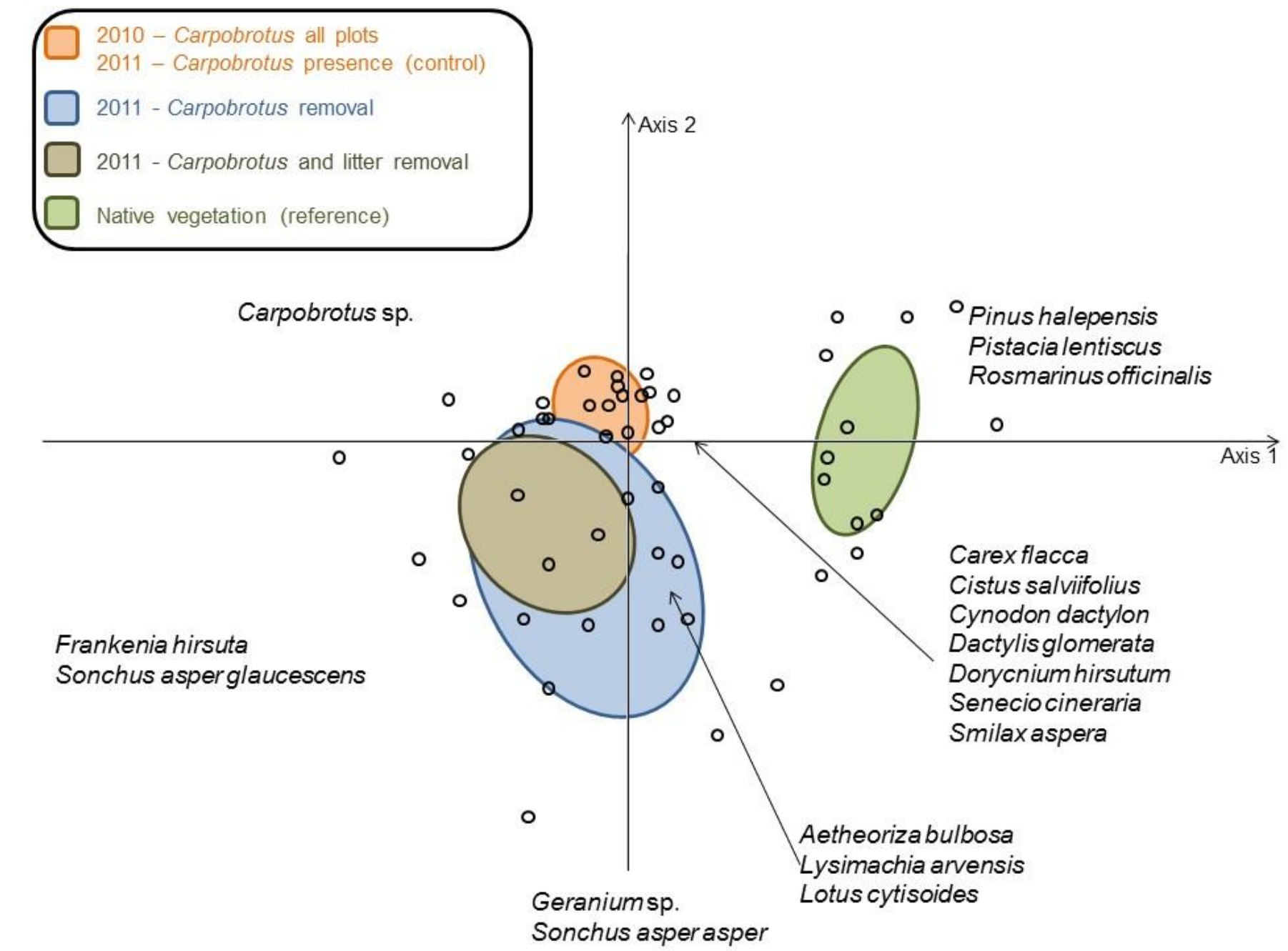

